Jurnal Info Kesehatan

Vol.18, No.1, June 2020, pp.80-95

P-ISSN 0216-504X, E-ISSN 2620-536X

DOI: 10.31965/infokes.Vol18.Iss1.429

Journal homepage: http://jurnal.poltekeskupang.ac.id/index.php/infokes

RESEA R C H

Open Access

\title{
Investigation of Women Employees in Family Health Centers of Eskişehir Province about Normal Birth and Caesarean Birth
}

\section{Türkan Geçer ${ }^{1 a^{*}}$}

${ }^{1}$ Department of Healthcare Management, South Russia University (IMBL), Russia

a Email address: turkan-gecer@ hotmail.com

Received: 31 May 2020

Revised: 29 June 2020

Accepted: 29 June 2020

\begin{abstract}
Unnecessary caesarean delivery continues to be an increasingly important problem in the world. Thanks to the information and training provided with the right resources, it is possible to reduce the caesarean rates and increase the normal birth rates with the right choices. This study aimed to learn the opinions of female employees in Eskişehir family health centers about normal and caesarean births, to determine important points and develop suggestions for these methods. The population of the study was 170 working women. Factor analysis, 16 items normal birth, and caesarean delivery scale were gathered under one factor, and this single factor explained $36.775 \%$ of the total variance. Results showed that when item-total correlation values of normal birth and caesarean section were examined, it was found that item-total correlation values of 16 items in the scale were between 0.407 and 0.759 . When item scores were examined, it was determined that there was consistency between the items. This research has shown that the majority of female workers prefer to giving births by caesarean section, while there is no clinical indication and they are suggested to normal delivery. As a result of the established DFA model, the fit indexes of the model were found to be among the perfect fit values $(\mathrm{x} 2 / \mathrm{df}=65.26 / 25 \leq 3)$.
\end{abstract}

Keywords: Caesarean Section, Family Health Centers, Normal Delivery, Scale.

\footnotetext{
*Corresponding Author:

Türkan Geçer

Department of Healthcare Management, South Russia University (IMBL), Russia

Email: turkan-gecer@hotmail.com

CThe Author(s) 2020. This article is distributed under the terms of the Creative Commons Attribution 4.0 International License (http://creativecommons.org/licenses/by/4.0/), which permits unrestricted use, distribution, and reproduction in any medium, provided you give appropriate credit to the original author(s) and the source, provide a link to the Creative Commons license, and indicate if changes were made. The Creative Commons Public Domain Dedication waiver (http://creativecommons.org/publicdomain/zero/1.0/) applies to the data made available in this article, unless otherwise stated.
} 


\section{INTRODUCTION}

Pregnant women should be informed and guided by correct sources about the appropriate delivery method. It is very important for labor to end with a healthy mother and baby. Raising the awareness of expectant mothers by providing accurate and sufficient information will facilitate compliance with the normal birth process. The prenatal, birth and postpartum periods are possible when midwives fully fulfill their responsibilities such as education, counseling, and care for both mother and baby (Ay et al., 2019).

Increases in caesarean rates are a universal problem and affect low, middle, and high-income countries, but may differ between countries depending on the human or financial resources available (WHO, 2018).

Although health personnel has good knowledge about the choice of birth, various factors originating from mothers and spouses influence the decision making about the choice of the birth type. Whilst the women's decision to choose the type of birth is effective, it is stated that the parent, spouse, close relatives, and mother-in-law follow. (Yakut, 2015).

Turkey shows a rapid increase of $48.1 \%$ caesarean rate in the period 2008-2013. (WHO, 2018). It requires a lot of research into its cause. As it is known, a caesarean is an unnatural form of birth (Chen \& Tan, 2019). Same time (WHO, 2018), caesarean delivery is associated with short and long term risks.

Despite this, caesarean delivery is increasing rapidly in the world. Therefore, conscious choices are vital to enable them to reduce caesarean rates (Ochieng Arunda, et al., 2020). However, thanks to the education and information given on birth, there is a decrease in caesarean rates by eliminating or decreasing normal birth fears (Khedr \& Eldeen, 2017).

Previous research has shown that education and information about normal births can significantly reduce caesarean rates and turn women's delivery preferences into normal and physiological deliveries (Yakut, 2015). The necessary training and are informed to reduce the rate of caesarean deliveries in Turkey. It aims to keep the caesarean birth rates in line with the World Health Organization (Aksoy et al., 2014).

\section{RESEARCH METHOD}

This study aimed to learn the thoughts of women employees about normal childbirth and caesarean birth in the family health centers of Eskişehir province, to determine the essential points and to make suggestions about these methods. The study population consisted of 170 working women in Eskişehir family health centers. We used a questionnaire as a data collection tool. Firstly, the aim and questions were determined. Secondly, a detailed literature review was done, and then the draft form was prepared by writing the items to be conveyed to the participants. After the preapplication way was evaluated, the final form was given to the participants and the questionnaire technique was applied. The researcher frequently received information about the status of the investigations by visiting family health centers in Eskişehir. Each item of the scale was scored from 1 to 5 where 1-Totally disagree, 2-Disagree, 3Undecided, 4-Agree, 5-Absolutely agree. The data obtained for this purpose were analyzed statistically using the SPSS package program. A new scale was developed in the LISREL program. In this study, reliability analysis, factor analysis, normality and homogeneity tests, t-test, chi-square analysis, and frequency distribution were also done. This research has been registered with the Eskişehir Provincial Health Directorate and 
Geçer, T. (2020). Investigation of Women Employees in Family Health Centers of Eskisehir Province about Normal Birth and Caesarean Birth. JURNAL INFO KESEHATAN, 18(1), 80-95. https://doi.org/10.31965/infokes.Vol18.Iss 1.429

has been given a license to research ethics with decision number 28345694-604.02 dated 23/03/2018. All respondents involved in this study were asked for approval and signed the consent form.

\section{RESULTS AND DISCUSSION}

This study involved 170 respondents who met the criteria; the respondents' characteristics are shown in table 1 below.

Table 1. Results of Item Analysis Regarding Normal Birth and Caesarean Birth Scale

$\begin{array}{ccccc}\text { Substances } & \text { Scale } & \text { Scale } & \text { Corrected } & \text { Cronbach } \\ \text { Mean if } & \text { Variance } & \text { Item-Total } & \text { 's Alpha if } \\ \text { Item } & \text { if Item } & \text { Correlation } & \text { Item } \\ \text { Deleted } & \text { Deleted } & & \text { Deleted }\end{array}$

1- Normal birth for mother

94.314

96.182

0.415

0.750 and child is more reliable than birth by caesarean section.

2- Normal birth is outdated,

$96.061 \quad 103.782$

0.007

0.778 caesarean birth is more up to date.

\section{3- The process of mother's} recovery takes more time with a caesarean birth.

4- Normal birth allows the baby's immune system to be strong.

5- The relationship between mother and baby in normal birth is stronger.

\begin{tabular}{llllll}
\hline 6- $\begin{array}{c}\text { The fear of birth in } \\
\text { improper environments }\end{array}$ & 95.218 & 99.666 & $0.180^{*}$ & 0.765 \\
and loss of time leads to & & & \\
birth by caesarean section. & & & \\
\end{tabular}

\begin{tabular}{lllll}
\hline 7- The mother is recovering & 93.958 & 96.481 & 0.531 & 0.746
\end{tabular}
easier and faster at normal birth.

\begin{tabular}{|c|c|c|c|c|}
\hline $\begin{array}{l}\text { 8- The education level of } \\
\text { mother candidates who } \\
\text { want to give birth by } \\
\text { caesarean section is high. }\end{array}$ & 95.814 & 101.126 & $0.131^{*}$ & 0.768 \\
\hline 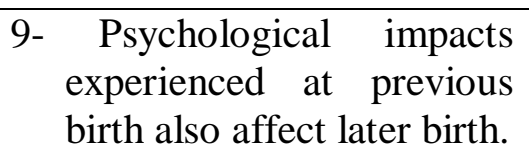 & 94.301 & 98.370 & 0.390 & 0.753 \\
\hline $\begin{array}{l}\text { 10-Epidural anesthesia, } \\
\text { hypnosis, and birth in }\end{array}$ & 94.578 & 100.056 & $0.274 *$ & 0.758 \\
\hline
\end{tabular}


water relieve fears of

normal birth.

\begin{tabular}{llllll}
\hline $\begin{array}{l}\text { 11-Caesarean surgery is } \\
\text { preferred when normal } \\
\text { delivery is not possible. }\end{array}$ & & 93.937 & 100.981 & $0.285^{*}$ & 0.758 \\
& & & & \\
\end{tabular}

12-Women who have had
their first birth by
caesarean section are
unlikely to have a normal
birth in the following
years.

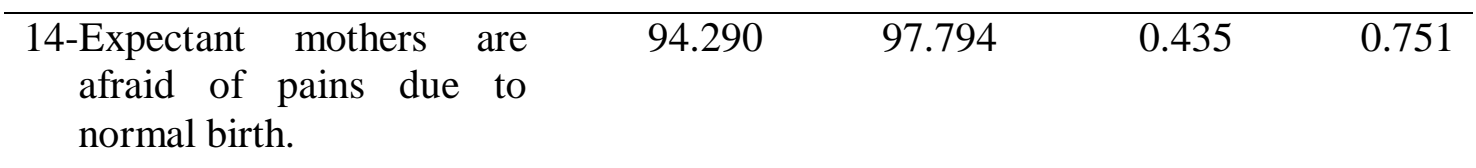

\begin{tabular}{lllll}
\hline 15-Although caesarean & 94.272 & 96.993 & 0.558 & 0.747 \\
surgery is performed in & & & \\
safe conditions today, & & & \\
some complications may & & & \\
occur.
\end{tabular}

\begin{tabular}{lllll}
\hline $\begin{array}{l}\text { 16- The most healthy birth for } \\
\text { mother and baby is normal } \\
\text { birth. }\end{array}$ & 93.972 & 95.463 & 0.597 & 0.743 \\
\hline $\begin{array}{l}\text { 17- Those who give birth by } \\
\text { caesarean section then can } \\
\text { not give birth normally. }\end{array}$ & 95.861 & 102.735 & $0.054 *$ & 0.773 \\
\end{tabular}

$\begin{aligned} & \text { 18-Caesarean birth rate } \\ & \text { decreases due to the } \\ & \text { pieces of training given to } \\ & \text { mothers. }\end{aligned}$
$\begin{aligned} & \text { 19-Birth by caesarean section } \\ & \text { results faster than a } \\ & \text { normal birth. }\end{aligned}$

\begin{tabular}{lllll}
\hline $\begin{array}{l}\text { 20-The expectant mothers } \\
\text { prefer normal birth } \\
\text { because they are afraid of } \\
\text { birth by caesarean section. }\end{array}$ & 95.678 & 102.580 & $0.070^{*}$ & 0.772 \\
\hline $\begin{array}{l}\text { 21-Caesarean section } \\
\text { negatively affects the } \\
\text { mother's psychology. }\end{array}$ & 95.596 & 100.734 & $0.190^{*}$ & 0.763 \\
\hline 22-Many mothers do not & 95.819 & 102.235 & $0.111^{*}$ & 0.767 \\
\hline
\end{tabular}


Geçer, T. (2020). Investigation of Women Employees in Family Health Centers of Eskisehir Province about Normal Birth and Caesarean Birth. JURNAL INFO KESEHATAN, 18(1), 80-95.

want to give birth because they are afraid of birth by caesarean section.

\begin{tabular}{|c|c|c|c|c|}
\hline $\begin{array}{l}\text { 23-Twin babies or triplet } \\
\text { expectant mothers prefer } \\
\text { birth by caesarean section. }\end{array}$ & 94.184 & 96.559 & 0.539 & 0.746 \\
\hline $\begin{array}{l}\text { 24- Mother candidates should } \\
\text { avoid a caesarean section } \\
\text { unless there is a medical } \\
\text { necessity. }\end{array}$ & 94.072 & 95.372 & 0.559 & 0.744 \\
\hline $\begin{array}{lcc}\text { 25-Mother and child } & \text { artality decrease } & \text { with } \\
\text { mortarean section. } & \end{array}$ & 95.502 & 107.894 & $-0.148 *$ & 0.783 \\
\hline $\begin{array}{l}\text { 26-Stress and economic } \\
\text { situation may affect the } \\
\text { fear of birth. }\end{array}$ & 94.572 & 98.333 & 0.387 & 0.753 \\
\hline $\begin{array}{l}\text { 27-Superstition, culture, and } \\
\text { civilization level of } \\
\text { society affect pain at birth. }\end{array}$ & 94.972 & 100.660 & $0.160 *$ & 0.765 \\
\hline
\end{tabular}

When the results of the item analysis of normal birth and caesarean surgery scale in Table 1 were examined, it has been determined that there were less than 0.30 items in the scale since the relationship should not be less than 0.30 (Büyüköztürk, 2002).

Table 2. Results of Item Analysis Regarding Normal Birth and Caesarean Birth Scale

$\begin{array}{ccccc}\text { Substances } & \text { Scale } & \text { Scale } & \text { Corrected } & \text { Cronbach's } \\ \text { Mean if } & \text { Variance if } & \text { Item-Total } & \text { Alpha if } \\ \text { Item } & \text { Item } & \text { Correlation } & \text { Item } \\ \text { Deleted } & \text { Deleted } & & \text { Deleted }\end{array}$

\begin{tabular}{lllll}
\hline $\begin{array}{l}\text { 1- Normal birth for mother } \\
\text { and child is more reliable } \\
\text { than birth by caesarean }\end{array}$ & & 61.634 & 0.565 & 0.870 \\
section. & & & \\
\hline $\begin{array}{l}3-\quad \text { With the caesarean } \\
\text { section, the mother's } \\
\text { recovery takes more time. }\end{array}$ & 62.168 & 61.351 & 0.632 & 0.867 \\
\hline $\begin{array}{l}\text { 4- Normal birth allows the } \\
\text { baby's immune system to be } \\
\text { strong. }\end{array}$ & 62.309 & 62.928 & 0.560 & 0.870 \\
\hline $\begin{array}{l}\text { 5- Mother and baby } \\
\text { relationship is stronger in } \\
\text { normal birth. }\end{array}$ & 62.321 & 61.039 & 0.583 & 0.869 \\
\hline $\begin{array}{l}\text { 7- The mother is recovering } \\
\text { more easily and quickly at a }\end{array}$ & 62.054 & 63.237 & 0.613 & 0.868 \\
\hline
\end{tabular}


normal birth.

9-Psychological impacts

62.397

65.933

0.378

0.878

experienced at previous

birth also affect later birth.

10- Epidural anesthesia,

62.674

66.581

0.314

0.880

hypnosis, and birth in the

water relieve the fear of

normal birth.

$\begin{aligned} & \text { 11- Caesarean surgery is } \\ & \text { preferred when normal birth }\end{aligned}$
is not possible.

\begin{tabular}{lllll}
\hline 13- Birth with caesarean & 62.580 & 60.059 & 0.651 & 0.866 \\
deprives the mother and the & & & \\
baby of many benefits of \\
normal birth.
\end{tabular}

$\begin{aligned} & \text { 14- Expectant mothers are } \\ & \text { afraid of pains due to }\end{aligned}$
normal birth.

\begin{tabular}{lllll}
\hline $15-\quad$ Although caesarean & 62.368 & 63.871 & 0.631 & 0.868 \\
surgery is performed in safe & & & \\
conditions today, some & & & & \\
complications may occur. & & & &
\end{tabular}

$\begin{aligned} & \text { 16- The most healthy birth } \\ & \text { for mother and baby is } \\ & \text { normal birth. }\end{aligned}$
$\begin{aligned} & \text { 18- Caesarean birth rate } \\ & \text { decreases due to the pieces } \\ & \text { of training given to mothers. }\end{aligned}$

23- Twin babies or triplet expectant mothers prefer

62.280

65.355

0.455

0.874 birth by caesarean section.

\begin{tabular}{llllll}
\hline $\begin{array}{l}24-\quad \text { Mother candidates } \\
\text { should avoid a caesarean } \\
\text { section unless there is a } \\
\text { medical necessity. }\end{array}$ & & 62.168 & 0.639 & 0.867 \\
\hline $\begin{array}{l}26-\text { Stress and economic } \\
\text { situation may affect the fear } \\
\text { of birth. }\end{array}$ & 62.668 & 65.505 & 0.405 & 0.877 \\
\end{tabular}


Geçer, T. (2020). Investigation of Women Employees in Family Health Centers of Eskisehir Province about Normal Birth and Caesarean Birth. JURNAL INFO KESEHATAN, 18(1), 80-95. https://doi.org/10.31965/infokes.Vol18.Iss 1.429

The results of the item analysis of normal birth and caesarean birth scale in Table 2 were examined. These substances were excluded from the scale since the relationship of the content with the other materials should not be less than 0.30. The level emphasized the suitability of removing these substances from the standard as they have elements below 0.30 (Büyüköztürk, 2002).

The number of participants to examine the distribution of the data was over 50. It was determined that the delivery of the information was not normal after KolmogorovSmirnova's analysis from the normal distribution analysis $(\mathrm{p}<0,05)$. Normal distribution with the other assumptions of the average media to be close to each other and the accuracy of the skewness between -1.5 and +1.5 should be examined according to the variables along with the normal distribution of these values was determined. In line with the central limit theorem, the sample volume is above 30, indicating that the distribution is close to the normality. As the sample volume was 170, it can be concluded that the distribution is not normal (Gürsakal, 2013). It was decided to carry out normal distribution analyzes for the study.

Table 3. Demographic Characteristics of Female Employees in Eskişehir Family Health Centers

\begin{tabular}{lrr}
\hline Age Group & Number & Percentage $\mathbf{\%})$ \\
\hline $18-22$ age group & 15 & 8.8 \\
\hline $23-27$ age group & 16 & 9.4 \\
\hline $28-32$ age group & 11 & 6.5 \\
\hline $33-37$ age group & 24 & 14.1 \\
\hline $38-42$ age group & 47 & 27.6 \\
\hline $42+$ age group & 57 & 33.5 \\
\hline Total & $\mathbf{1 7 0}$ & $\mathbf{1 0 0 . 0}$ \\
\hline Educational Status & 6 & \\
\hline Primary school & 65 & 3.5 \\
\hline High school & 35 & 20.6 \\
\hline Associate & 44 & 25.9 \\
\hline Graduate & 66 & 38.8 \\
\hline Postgraduate & 19 & 11.2 \\
\hline Total & $\mathbf{1 7 0}$ & $\mathbf{1 0 0 . 0}$ \\
\hline Marital Status & & \\
\hline Single & 40 & 23.5 \\
\hline Married & 130 & 76.5 \\
\hline Total & $\mathbf{1 7 0}$ & $\mathbf{1 0 0 . 0}$ \\
\hline Occupation & & \\
\hline Doctor & 25 & 14.7 \\
\hline Nurse & 58 & 34.1 \\
\hline Midwife & 66 & 38.8 \\
\hline Technician & 4 & 2.4 \\
\hline Office staff & 2 & 1.2 \\
\hline Other & 15 & 8.8 \\
\hline Total & $\mathbf{1 7 0}$ & $\mathbf{1 0 0 . 0 0}$ \\
\hline & &
\end{tabular}


Based on table 3 above, it was shown that most participants were more than 42 years old (33.5\%), 38.8\% had graduate degrees, $76.5 \%$ married, and $38.8 \%$ worked as midwives. When descriptive statistics were analyzed, normal birth and caesarean birth levels were found below ( $\bar{x}=66.49$ ). The highest level of normal birth and caesarean birth scales with 4.46 was "Caesarean birth is preferred when normal birth is not possible". The lowest level of substance with 3.82 was "Epidural anesthesia, hypnosis, and water birth resolve the fear of normal birth".

When the item-total correlation values of normal birth and caesarean birth scale were examined, the total correlation values of 16 items in the range were found between 0.407 and 0.759 . When the item scores were examined, it was determined that there was consistency among the elements. As a result of the factor analysis, 16-item normal birth and caesarean section were collected under a single factor, and this single factor explained $36.775 \%$ of the total variance (Büyüköztürk, 2002). This may give us a good result when we apply a factor load value of 0.45 or higher. But this does not mean that only 0.45 and above would be taken as the value of this value can be reduced to 0.30 and emphasized that it would be suitable for a small number of substances. Therefore, items below 0.30 were removed from the scale.

According to the factor loadings, the distance between the items in which the substances are collected should be at least 10\% (Büyüköztürk, 2002). As a result of factor analysis, two factors were applied as one factor, and no rotation was performed (Çokluk et al, 2014). It was stated that rotation could not be the only factor in a single factor and that the rotation would be useful in the interpretation of two or more elements. Cronbach Alpha value was used in the calculation of the internal consistency of the factors, and Cronbach's Alpha reliability coefficient value for the internal consistency of the scale was 0.879 . Cronbach's alpha value of 0.70 and above is reported to be reliable (Cortina, 1993).

Table 4. Factor 1 Mother and Baby

\begin{tabular}{lc}
\hline 1- The most healthy birth for mother and baby is normal birth. & 0.781 \\
\hline $\begin{array}{l}\text { 2- Birth with caesarean deprives the mother and the baby of many } \\
\text { benefits of normal birth. }\end{array}$ & 0.734 \\
\hline $\begin{array}{l}\text { 3- Unless there is a medical requirement, mother candidates should } \\
\text { avoid birth by caesarean. }\end{array}$ & 0.721 \\
\hline 4- With the caesarean section, the mother's recovery takes more time. & 0.701 \\
\hline $\begin{array}{l}\text { 5- Although caesarean birth is performed under safe conditions } \\
\text { today, some complications may occur. }\end{array}$ & 0.695 \\
\hline $\begin{array}{l}\text { 6- The mother is recovering more easily and quickly at a normal } \\
\text { birth. }\end{array}$ & 0.692 \\
\hline $\begin{array}{l}\text { 7- Mother and baby relationship is stronger in normal birth. } \\
\text { 8- Normal birth is more reliable than caesarean birth for mother and } \\
\text { baby. }\end{array}$ & 0.660 \\
\hline 9- Normal birth allows the baby's immune system to be strong. & 0.653 \\
\hline $\begin{array}{l}\text { 10- Expectant mothers are afraid of pains due to normal birth. } \\
\text { 11- Twin baby or triplet expectant mothers prefer birth by caesarean } \\
\text { section. }\end{array}$ & 0.632 \\
\hline $\begin{array}{l}\text { 12- With the pieces of training given to mother candidates, the } \\
\text { caesarean delivery rate decreases. }\end{array}$ & 0.519 \\
\hline $\begin{array}{l}\text { 13- Stress and economic situation may affect the fear of birth. } \\
\text { 14- Psychological impacts experienced at previous birth also affect } \\
\text { later birth. }\end{array}$ & 0.518 \\
\hline
\end{tabular}


15- Caesarean birth is preferred when normal birth is not possible. 0.397

16- Epidural anesthesia, hypnosis, and birth in the water relieve the fear of normal birth.

The factor load of mother and baby factor was determined to be between 0.371 and 0.781 .

Normal birth and caesarean birth levels were determined from small to large to determine the lower and upper groups of $27 \%$ of the participants. The first 46 and the highest 46 values were examined in $27 \%$ of normal birth and caesarean surgery. It was determined that the upper and lower values of $27 \%$ used in the decision making of substances were meaningful for all substances. $* *(p<0.01)$. After the $t$-test for lower and upper normal birth and caesarean section, normal birth and caesarean birth were found to be different. Up; $(\overline{\mathrm{x}}=75.6522)$ Low; $(\overline{\mathrm{x}}=56.2174)$ is higher.

Chi-square analysis was performed to examine the relationship among the answers given to this question according to the marital status of the participants. According to the chi-square analysis, the relationship between marital status and this question was not statistically significant at $95 \%$ confidence level $(\mathrm{x} 2=0.774 ; \mathrm{p}=0.379$; $\mathrm{p}>0.05)$. There was a low level of relationship between marital status and respondents (Cramer's V-0.067).

Values taken by the variable generate certain groups. The t-test is a special variability analysis that distinguishes the elements in these groups from one another (Sweet \& Grace-Martın, 2012). According to the independent sample of t-test results, the difference of the participants according to marital status was statistically significant at a 95\% confidence level. In this context, since the p-value was less than 0.05 ( $\mathrm{p}=$ 0.038), it can be stated that there was a difference between the number of participants in "Normal Birth and Caesarean Birth" $(\mathrm{t}=2.091, \mathrm{p}=0.038, \mathrm{p}<0.05)$. The answers given by the single ones ( $\overline{\mathrm{x}}=68.93)$ were higher than those given by the married $(\overline{\mathrm{x}}=65.75)$.

The chi-square analysis was conducted to examine the relationship between the importance of the concept of confidentiality in determining the type of birth according to the marital status of the participants. According to the chi-square analysis, the significance of the concept of privacy in determining the marital status and the way of birth was not statistically significant at a 95\% confidence level $(\mathrm{x} 2=4.497 ; \mathrm{p}=0.106$; $\mathrm{p}>0.05$ ). There was a low level of relationship between participants' responses to marital status and whether confidentiality was important in deciding the way of birth (Cramer's V-0.163).

Table 5. Distribution of the question

\begin{tabular}{|c|c|c|c|}
\hline \multicolumn{4}{|c|}{ What is the most reliable form of birth? } \\
\hline Marital Status & Normal Birth & Caesarean Birth & $\mathbf{p}$ \\
\hline Single & $38(95.0 \%)$ & $2(5.0 \%)$ & 1.000 \\
\hline Married & $121(93.1 \%)$ & $9(6.9 \%)$ & \\
\hline \multicolumn{4}{|c|}{ Are you having a health problem after birth with a caesarean section? } \\
\hline Marital Status & Yes & No & $\mathbf{p}$ \\
\hline Single & $1(20.0 \%)$ & $4(80.0 \%)$ & 1.000 \\
\hline Married & $19(23.8 \%)$ & $61(76.3 \%)$ & \\
\hline \multicolumn{4}{|c|}{ Which form of delivery affects the baby negatively? } \\
\hline Marital Status & Normal Birth & Caesarean & $\mathbf{p}$ \\
\hline
\end{tabular}




\begin{tabular}{lrrrr}
\hline \multicolumn{5}{c}{ Birth } \\
\hline Single & $3(7.5 \%)$ & $16(40.0 \%)$ & $21(52.5 \%)$ & 0.508 \\
\hline Married & $10(7.7 \%)$ & $65(50.0 \%)$ & $55(42.3 \%)$ & \\
\hline
\end{tabular}

Chi-square analysis was performed to examine the relationship between the answers given to the question of what is the most reliable method of delivery according to the marital status of the participants. According to the chi-square analysis, the relationship between the marital status and the answers to the most reliable method of delivery was not statistically significant at a 95\% confidence level $(p=1.000 ; p>0.05)$. There was a low level of relationship between the marital status and the answers of the participants (Cramer's V-0.033).

When the distribution of the answers given to the question "Which cost of birth is less?", the majority of the doctors said normal birth $(100.0 \%)$, nurses $(98.3 \%)$, midwives (100.0\%), technicians (100.0\%), office staffs $(100.0 \%)$, and other occupational groups $(93.3 \%)$.

Chi-square analysis was performed to investigate the relationship between the caesarean section and the health problems after birth. The relationship between marital status and the answers to the question of whether there is a health problem after a caesarean birth was not statistically significant at a 95\% confidence level $(p=1.000$; $\mathrm{p}>0.05$ ). There was a low level of relationship between the marital status of the participants and their answers to whether they had a health problem after a caesarean birth (Cramer's V-0.021).

Chi-square analysis was performed to examine the relationship among the answers given to the question of which birth form the baby was adversely affected. The relationship between the marital status and the answers given to the question of what type of birth the baby has been adversely affected was not statistically significant at a $95 \%$ confidence level $(\mathrm{x} 2=1.354 ; \mathrm{p}=0.508 ; \mathrm{p}>0.05)$. The relationship between the marital status of the participants and the answers given to the question of which birth form the baby is adversely affected was not statistically significant at a 95\% confidence level. There was a low-level relationship between the answers given to the question of marital status and how the baby is adversely affected (Cramer's V-0.093).

Table 6. Distribution of How These Births Happened of Birth According to Professional, Educational, and Age status

\begin{tabular}{lccc}
\hline \multicolumn{1}{c}{ Variable } & Normal Birth & Caesarean Birth & Total \\
\hline Profession & $8(17.4 \%)$ & $38(82.6 \%)$ & $46(100.0 \%)$ \\
Doctor & $31(47.7 \%)$ & $34(52.3 \%)$ & $65(100.0 \%)$ \\
Nurse & $29(31.5 \%)$ & $63(68.5 \%)$ & $92(100.0 \%)$ \\
Midwife & $3(100.0 \%)$ & $0.0 \%$ & $3(100.0 \%)$ \\
Technician & $4(100.0 \%)$ & $0.0 \%$ & $4(100.0 \%)$ \\
Office staff & $12(54.5 \%)$ & $10(45.5 \%)$ & $22(100.0 \%)$ \\
Other & $87(37.5 \%)$ & $145(62.5 \%)$ & $232(100.0 \%)$ \\
Total & & & \\
Educational Status & $6(60.0 \%)$ & $4(40.0 \%)$ & $10(100.0 \%)$ \\
Primary School & $12(41.4 \%)$ & $17(58.6 \%)$ & $29(100.0 \%)$ \\
High School & $28(41.2 \%)$ & $40(58.8 \%)$ & $68(100.0 \%)$ \\
Associate & $33(36.4 \%)$ & $58(63.6 \%)$ & $91(100.0 \%)$ \\
Graduate & $9(31.0 \%)$ & $20(69.0 \%)$ & $29(100.0 \%)$ \\
Postgraduate & $88(40.2 \%)$ & $139(59.8 \%)$ & $227(100.0 \%)$ \\
Total & & & \\
Age Group & & &
\end{tabular}




\begin{tabular}{lrcc}
\hline 18-22 Age group & $1(50.0 \%)$ & $1(50.0 \%)$ & $2(100.0 \%)$ \\
23-27 Age group & $1(100.0 \%)$ & $0.0 \%$ & $1(100.0 \%)$ \\
28-32 Age group & $2(100.0 \%)$ & $0.0 \%$ & $2(100.0 \%)$ \\
$33-37$ Age group & $2(20.0 \%)$ & $8(80.0 \%)$ & $10(100.0 \%)$ \\
$38-42$ Age group & $13(36.1 \%)$ & $23(63.9 \%)$ & $36(100.0 \%)$ \\
$42+$ Age group & $25(32.1 \%)$ & $53(67.9 \%)$ & $78(100.0 \%)$ \\
Total & $44(45.83 \%)$ & $52(54.17 \%)$ & $96(100.0 \%)$ \\
\hline
\end{tabular}

Table 6 Showed the distribution of the way of giving birth according to the profession. The majority of the doctors said giving caesarean birth $(82.6 \%)$, most nurses giving caesarean birth (52.3\%), most midwives giving caesarean birth (68.5\%), technicians $(100,0 \%)$, office staff $(100,0 \%)$, other profession groups $(54.5 \%)$ said that normal birth.

According to educational status, primary school graduates were determined to have normal birth $(60.0 \%)$, caesarean birth; high school $(58.6 \%)$ associate degree $(58.8 \%)$, bachelor's degree $(63.6 \%)$, post graduate degree $(69.0 \%)$.

Furthermore, we see an equal distribution with (50.0\%) at the age of 18-22. 23-27 aged said that normal birth with (100.0\%), 28-32 aged said that normal birth, too with (100.0\%). 33-37 aged (80.0\%), 38-42 aged (63.9\%), and 42+ aged (67.9\%) said that caesarean birth.

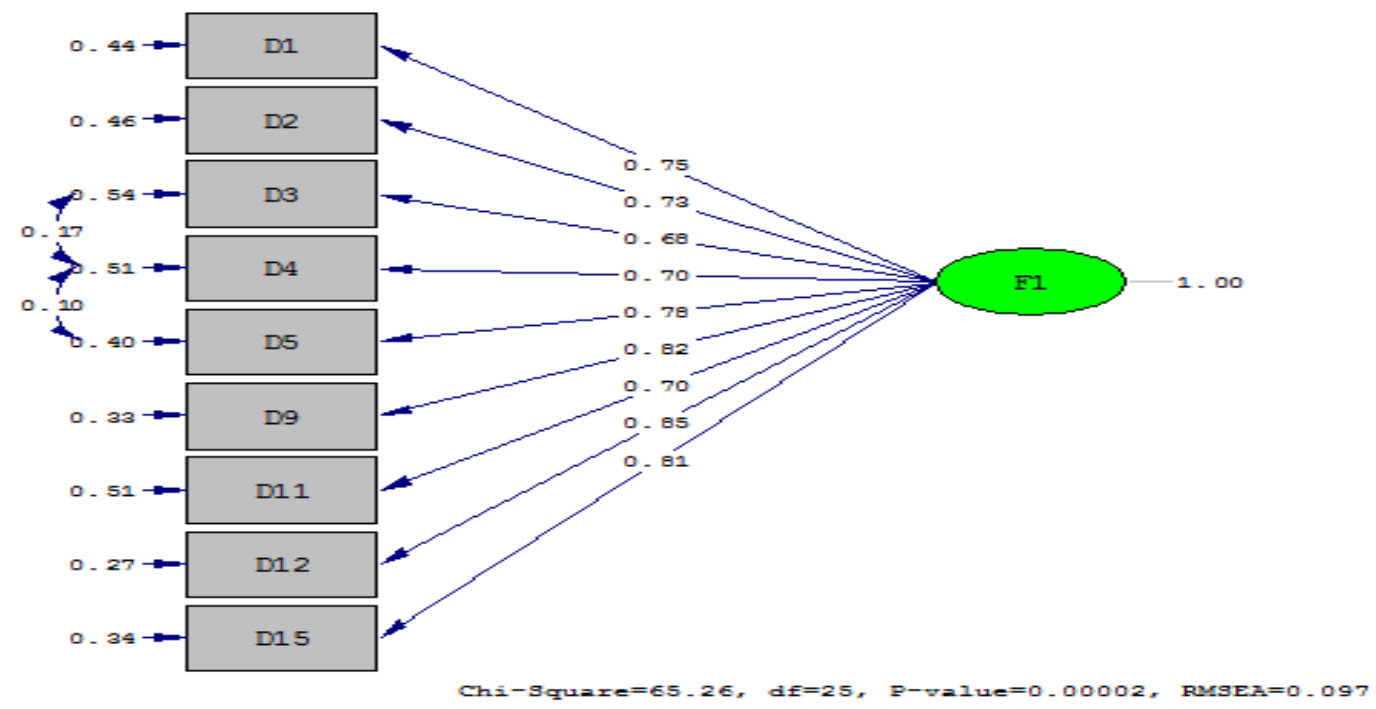

\section{Figure 1: DFA Path Diagram of Normal Birth and Caesarean Birth}

In DFA analysis of normal birth and caesarean birth scale, the sub-dimension of the range was named as F1, with a factor of 0.85 on the size of F1, and the variable "The most healthy birth for mother and baby is normal birth" was determined as the most effective variable. It is possible to reach a general alignment by measuring the model and detailed analysis of structural divisions (Diamantopoulos \& Siguaw 2000).

When table 2 was examined, the RMSEA value was between the acceptable fit index $($ RMSEA $=0.097)$, the SRMR value was between the perfect fit index $($ SMRM = $0.039)$, the NFI value was between the acceptable fit index (NFI $=0.935)$, and the NNFI value was within the acceptable fit index ( NNFI $=0.940)$, the CFI value was within the perfect fit index $(\mathrm{CFI}=0.959)$, the GFI value was within the acceptable compliance index $(\mathrm{GFI}=0.927)$, the AGFI value was within the acceptable alignment index (AGFI 
$=0.868)$ and the IFI value was an index $(\mathrm{IFI}=0,959)$ RFI was within the acceptable fit index $(\mathrm{RFI}=0,907)$ are seen.

Table 7. Result of confirmatory factor analysis, one factor was found to have excellent compliance value $(\mathrm{X} 2 / \mathrm{df}=65.26 / 25 \leq 3)$.

\begin{tabular}{cccc}
\hline $\begin{array}{c}\text { Compliance } \\
\text { Criteria }\end{array}$ & Perfect Fit & Acceptable Compliance & $\begin{array}{c}\text { Values of } \\
\text { Developed Scale }\end{array}$ \\
\hline$\chi 2 / s d$ & $\leq 3$ & $\leq 5$ & 2.61 \\
\hline RMSEA & $0<\mathrm{RMSEA}<0.05$ & $0.05 \leq \mathrm{RMSEA} \leq 0.10$ & 0.097 \\
\hline SRMR & $0 \leq \mathrm{SRMR}<0.05$ & $0.05 \leq \mathrm{SRMR} \leq 0.10$ & 0.039 \\
\hline NFI & $0.95 \leq \mathrm{NFI} \leq 1$ & $0.90 \leq \mathrm{NFI} \leq 0.95$ & 0.935 \\
\hline NNFI & $0.95 \leq \mathrm{NNFI} \leq 1$ & $0.90 \leq \mathrm{NNFI} \leq 0.95$ & 0.940 \\
\hline CFI & $0.95 \leq \mathrm{CFI} \leq 1$ & $0.90 \leq \mathrm{CFI} \leq 0.95$ & 0.959 \\
\hline GFI & $0.95 \leq \mathrm{GFI} \leq 1$ & $0.90 \leq \mathrm{GFI} \leq 0.95$ & 0.927 \\
\hline AGFI & $0.90 \leq \mathrm{AGFI} \leq 1$ & $0.85 \leq \mathrm{AGFI} \leq 0.90$ & 0.868 \\
\hline IFI & $0.95 \leq \mathrm{IFI} \leq 1$ & $0.90 \leq \mathrm{IFI} \leq 0.95$ & 0.959 \\
\hline RFI & $0.95 \leq \mathrm{RFI} \leq 1$ & $0.90 \leq \mathrm{RFI} \leq 0.95$ & 0.907 \\
\hline
\end{tabular}

(Source: Schermelleh-Engel et al., 2003).(RMSEA: Root Mean Square Error of Approximation, SRMR: Standardized Root Mean Square Residual, GFI: Goodness of Fit Index, AGFI: Adjusted Goodness of Fit Index)

Mothers and personals in prenatal care services may need to provide strong evidence to prevent an increased rate of caesarean birth (Roberts et al., 2012). Research has shown that education and information for normal birth through the reduction of caesarean section rates, mothers expect more normal and natural births (Yakut, 2015). However, studies conducted in recent years have seen an increase in the caesarean rate in the world and Turkey. Studies on the subject indicate that caesarean delivery is a preferred mode of birth in the presence of a severe threat to both the woman and her baby. In contrast, the rate of caesarean delivery increases rapidly in the world (Gözükara \& Eroğlu, 2011). When the birth type of women was examined, it was found that $55.5 \%$ had delivered by caesarean section (Keskin, 2018). In our findings, when the distribution of delivery type according to age was examined, it was found that 18-22 age group $(50.0 \%)$ were equal $(50.0 \%)$, normal birth with $23-27$ age group (100.0\%), and normal birth with 28-32 age group (100.0\%). Reported that there was birth by caesarean section at 33-37 age group (80.0\%), at 38-42 age group (63.9\%), section at age 42 and over $(67.9 \%)$.

When the distribution of the way of giving birth according to educational status is examined; while the majority of primary school graduates were determined to have normal birth $(60.0 \%)$, caesarean birth; high school $(58.6 \%)$, associate degree $(58.8 \%)$, bachelor's degree $(63.6 \%)$, post graduate degree $(69.0 \%)$.

Similar to our findings, a study stated that there was a significant difference between maternal age with the type of birth. Women aged of 25 and under were more likely to give normal birth (Keskin, 2018). Of the women who participated in the study, $56.6 \%$ of the group who preferred vaginal delivery was in the 20-29 age group, while $41.5 \%$ of those who preferred caesarean delivery were in the 30-39 age group. Similar to other studies in the literature, the rate of delivery by caesarean section increases with increasing age at delivery. The difference between birth preferences and age groups of women was found to be highly significant ( $\mathrm{p}<0.001$ ) (Karabulutlu, 2012). Ergöl \& Kürtüncü (2014), reported that there was no significant difference between the mean age of the women, the mode of delivery, and the level of education ( $p>0.05)$. (Yaşar, 
2006) in his study also stated that primary school graduates women prefer caesarean delivery. It also states that caesarean delivery preference is due to the personal characteristics of women rather than an educational level.

As seen above, the rate of caesarean birth increases as the education level of the participants. Caesarean, which is highly preferred in recent years, needs to be further understood about the benefits and damages of birth (Kara, 2004).

When the distribution of delivery type by profession was examined, it was determined that the majority of doctors mentioned delivered by caesarean section $(82.6 \%)$, while nurses $(52.3 \%)$ and midwives $(68.5 \%)$ answered by caesarean section. Technicians and office staffs (100.0\%), and other occupational groups $(54.5 \%)$ responded with normal birth. In our study, the concept of privacy is essential in deciding the type of delivery according to marital status. The answers given to the question were single with $61.5 \%$, the married participants stated that they were important with $53.8 \%$. In the other literature, which proves the importance of privacy, $15.1 \%$ of nurses and midwives think that an appropriate environment should be provided for an ideal delivery room (that the patient's relatives can enter, and patient privacy is provided (Güleç et al., 2018). (Duman, 2006) in his study, he specified that all participants stated that the cost of caesarean delivery is higher.

Similarly, which mode of delivery is less costly? When the distribution of the answers given to the question by profession was examined, it was determined that the majority of doctors stated normal births (100.0\%), nurses (98.3\%), midwives (100.0\%), technicians (100.0\%), office staffs (100\%). Recently, policies and strategies have been developed and implemented rapidly in the world and our country to decrease caesarean rates and increase normal births. Birth and Caesarean Section Management Guide published by the Ministry of Health in 2010 stated strategies for reducing caesarean section and increasing normal births. In the implementation of these strategies, it is very important to raise awareness of the society and especially the mothers about the way of birth and to increase their self-confidence by providing education (Yakut., 2015).

The answers given to the question of which type of delivery has negative effects; single people none responded with $52.5 \%$ and married people with a caesarean delivery with $50.0 \%$.

In the study conducted in the literature, when the respondents were asked which form of delivery is adversely affected, $43.5 \%$ of the respondents said normal birth, and $56.5 \%$ of them responded to caesarean delivery (Duman, 2006).

According to the answers given by those who gave birth by caesarean section, when the distribution of the question of whether there was a health problem after delivery by caesarean section according to marital status, singles answered no with $80.0 \%$, while married ones gave no with $76.3 \%$.

Are you afraid of normal birth? The female employees, who are married,gave the answer no with $54.6 \%$, singles said no with $62.5 \%$.

As a result of the analysis (Duman, 2006), as stated in his study, the most reliable method of birth was a normal birth, and $58.5 \%$ of the working health personnel preferred caesarean birth.

When the distribution of the question of what is the most reliable type of birth by marital status was examined, the unmarried respondents gave normal birth response with $95.0 \%$. In comparison, the respondents who married gave a normal birth response with $93.1 \%$. As can be seen, there was no significant difference between non-married and married answers. The majority of the working women in family health centers prenatal care services in Eskişehir province preferred the birth by caesarean in their 
births, and they suggest normal birth in their recommendations. (Özkaya, 2005) states that caesarean rates increase rapidly every day.

In this study, it was found that normal birth was more reliable than caesarean birth. Although female workers have stated that normal birth is more reliable, it may be a research topic why caesarean delivery is their birth and why normal birth is recommended in the research.

\section{CONCLUSION}

In this study, it was found that normal birth was more reliable than caesarean birth. Although female workers have stated that normal birth is more reliable, it may be a research topic of why caesarean delivery is their birth preference and why normal birth is recommended to reduce caesarean rates and increase normal birth rates. First of all, for the personnel working in family health centers maternal long-term programs should be given more space. Besides, as in normal birth, the risks of caesarean delivery should be emphasized more. Public spots should be described more widely. In parallel with this situation, the age of having children increases in our country, which increases the level of education. As can be seen in this study, as education level and age increases, caesarean delivery rates increase. Therefore, our expectant mothers should not delay childbearing due to education. Therefore, it is recommended that they have children at an early age.

\section{REFERENCES}

Ay, F., Ekmekçi, K. A., Batuhan, F., \& Oğuz, A. (2019). Kadınlar Sosyal Medyada Normal Doğum Eylemi ile İlgili Ne Paylaşıyor?. ACU Sağlık Bil Derg, 10(1), 4954. https://doi.org/10.31067/0.2019.106

Aksoy, H., Özyurt, S., Aksoy, Ü., Açmaz, G., İdem Karadağ, Ö., \& Alparslan Babayiğit, M. (2014). Hastanemizdeki sezaryen hızı ve endikasyon dağılımları 1şı̆̆ında Türkiye'de sezaryen ile doğuma genel bakış. Kocaeli Tıp Dergisi, 3(3), $1-7$.

Büyüköztürk, Ş. (2002). Sosyal bilimler için veri analizi el kitabı. Ankara: Pegem A Yayıncilık.

Chen, H., \& Tan, D. (2019). Cesarean section or natural childbirth? cesarean birth may damage your health. Frontiers in psychology, 10(351), 1-7. https://doi.org/10.3389/fpsyg.2019.00351

Cortina, J. M. (1993). What is coefficient alpha? An examination of theory and applications. Journal of Applied Psychology, 78(1), 98-104. https://doi.org/10.1037/0021-9010.78.1.98

Çokluk,Ö.,Şekercioğlu,G. \& Büyüköztürk,Ş. (2014). Sosyal bilimler için çok değişkenli istatistik SPSS ve LISREL uygulamaları. Ankara:Pegem Akademi.

Diamantopoulos A.,\& Siguaw JA. (2000). Introducing LISREL: A Guide For the uninitiated. London: Sage Publications.

Duman, Z. (2006). Sağlık çalışanlarının normal doğum ve sezaryen ile ilgili düşünceleri. Sağlık Bilimleri Enstitüsü. Kadın Hastalıkları ve Doğum Hemşireliği Anabilim Dal1, Afyon Kocatepe Üniversitesi.Yüksek Lisans Tezi. Afyonkarahisar.

Ergöl, Ş \& Kürtüncü, M. (2014). Bir üniversite hastanesinde kadınların sezaryen doğum tercihlerini etkileyen faktörler. Hacettepe Üniversitesi Hemşirelik Fakültesi Dergisi 1(3): 26-34.

Gözükara, F., \& Eroğlu, K. (2011). Sezaryen doğum artışını önlemenin bir yolu:“bir kez sezaryen hep sezaryen” yaklaşımı yerine sezaryen sonrası vajinal doğum ve 
Geçer, T. (2020). Investigation of Women Employees in Family Health Centers of Eskisehir Province about Normal Birth and Caesarean Birth. JURNAL INFO KESEHATAN, 18(1), 80-95. https://doi.org/10.31965/infokes.Vol18.Iss 1.429

hemşirenin rolleri. Hacettepe Üniversitesi Hemşirelik Fakültesi Dergisi, 18(2), 89-100.

Gürsakal, N. (2013). Çıkarımsal İstatistik: İstatistik 2. Bursa: DORA Yayınları

Güleç Şatır D., Ünsal Atan Ş., Taner, A. \& Gün, S. (2018). Kadın doğum kliniklerinde çalışan hemşire ve ebelerin doğal doğum ve doğumda uygulanan müdahalelere ilişkin bilgi ve görüşlerinin belirlenmesi. Hemşirelikte Eğitim ve Araştırma Dergisi, 15(4), 222-227. http://doi.org/10.5222/HEAD.2018.222

Kara, F. Ş. (2004). Haseki Eğitim ve Araştırma Hastanesi kadın hastalıkları ve doğum kliniğinde iki yıllık sürede sezaryen doğumların değerlendirilmesi. Sağllk Bakanlı̆̆ Haseki Ĕgitim ve Araştırma Hastanesi, Kadın Hastalıkları ve Doğum Kliniği, İstanbul.

Karabulutlu, Ö. (2012). Kadınların doğum şekli tercihlerini etkileyen faktörler. I. Ü.F.N. Hemşirelik Dergisi, 20 (3), 210-218.

Keskin, F. (2018). Doğum şekli ve maternal bağlanmaya etki eden faktörlerin incelenmesi. İnönü Üniversitesi Sağlık Bilimleri Enstitüsü, Hemşirelik Anabilim Dalı. Yüksek Lisans Tezi,.Malatya.

Khedr, N. F. H., \& Eldeen, M. S. (2017). Effect of healthy instructions on reducing pregnant women's fear of normal delivery and preferences for cesarean delivery. American Journal of Nursing Science, 6, 176-184. https://doi.org/10.11648/j.ajns.20170603.15

Ochieng Arunda, M., Agardh, A., \& Asamoah, B. O. (2020). Cesarean delivery and associated socioeconomic factors and neonatal survival outcome in Kenya and Tanzania: analysis of national survey data. Global Health Action, 13(1), 1748403. https://doi.org/10.1080/16549716.2020.1748403

Özkaya, O. (2005). Süleyman Demirel Üniversitesi kadın hastalıkları ve doğum kliniğindeki 5 yıllık doğum oranları ve sezaryen endikasyonları. SD $\ddot{U}$ T $p$ Fakültesi Dergisi, 12(4), 36-39.

Roberts C.L., Algert C.S., Ford J.B., Todd A.L., Morris J.M. (2012). Pathways to a rising caesarean section rate: a population-based cohort study. BMJ Open. 2(5), 17. http://org.doi/101136/bmjopen-2012-001725.

Schermelleh-Engel, K., Moosbrugger, H., \& Müller, H. (2003). Evaluating the fit of structural equation models: Tests of significance and descriptive goodness-of-fit measures. Methods of psychological research online, 8(2), 23-74.

Sweet, S.,\& Grace- Martin, K. (2012). Data analysis with SPSS: A first course in applied statistics,p.146, 4th.ed. Allyn \& Bacon.

Yakut, E. Y. (2015). Gebelerin doğum şekline ilişkin görüş ve tercihleri (Master's thesis, Adnan Menderes Üniversitesi, Sağlık Bilimleri Enstitüsü).

Yaşar, Ö. (2006). Primipar kadınların doğum tercihleri ve bunu etkileyen faktörler (Master's thesis, Afyon Kocatepe Üniversitesi, Sağlık Bilimleri Enstitüsü).

WHO. (2018). WHO Recomendations Non-Clinical Interventions to reduce unnecessary caesarean sections. World Health Organization.

WHO. (2018). Global Health Observatory Data Repository Births by Caesarean Section Data by Country. Geneva: World Health Organization. 